\title{
Assessing cetacean body condition: Is total lipid content in blubber biopsies a useful monitoring tool?
}

\author{
Joanna L. Kershaw ${ }^{1}$ (D) | Andrew Brownlow ${ }^{2}$ | Christian A. Ramp ${ }^{1,3}$ | Patrick J.O. Miller ${ }^{1}$ (D) । \\ Ailsa J. Hall ${ }^{1}$
}

${ }^{1}$ Sea Mammal Research Unit, Scottish Oceans Institute, University of St Andrews,

St Andrews, UK

${ }^{2}$ Scottish Marine Animals Strandings Scheme, SAC Consulting Veterinary Services, Inverness, UK

${ }^{3}$ Mingan Island Cetacean Study, 378 Bord de la Mer, Longue-Pointe-de-Mingan, Quebec,

Canada

\section{Correspondence}

Joanna L. Kershaw, Sea Mammal Research Unit, Scottish Oceans Institute, University of St Andrews, St Andrews, UK

Email: jk49@st-andrews.ac.uk

Funding information

Department for Environment, Food and Rural Affairs; Marine Scotland; Natural Environment Research Council; Strategic Environmental Research and Development Program

\section{Abstract}

1. Measuring the energy stores, or body condition, of cetaceans is vital for monitoring population health. Cetaceans are exposed to a range of anthropogenic stressors, including, for example, noise, contaminants, habitat degradation, reduced prey availability, ship strike, and entanglement. Tools to assess body condition in these inaccessible and vulnerable animals are required to better understand the energetic consequences of anthropogenic stressors that can impact population health and, ultimately, conservation status.

2. Remotely obtained, dart biopsy samples are becoming an increasingly standard method of tissue collection from live, large cetaceans. Here, the potential applicability of using total lipid content in such biopsy samples to estimate overall body condition was assessed using full-depth dorsal blubber samples from stranded ziphiids $(n=8)$ and balaenopterids $(n=9)$. First, variation in total lipid content through the blubber depth was investigated to assess the representativeness of shallow-depth dart biopsies taken from live animals. Second, how lipid content varies by species, cause of death, sex, age class, and morphometric indices of body condition was assessed to evaluate what information about individual energy stores can be gained from such analyses.

3. Total lipid content in dorsal, shallow-depth blubber biopsy samples from both cetacean families provides little information on overall body condition. Stratification of lipid content through the blubber layer in the balaenopterids means that superficial biopsy samples are not representative of the lipid stores available for mobilization through the rest of the tissue. A lack of variation in blubber lipid content, both within and between the ziphiid individuals, resulted in no ability to correlate these measures with morphometrics or other health, sex, or age class covariates.

4. Other potential markers in the blubber from remote biopsy sampling should be explored in order to further develop robust tools for estimating the body condition of free-ranging cetaceans.

\section{KEYWORDS}

adipose tissue, balaenopterids, blubber, body condition, diving physiology, lipids, ziphiids 


\section{1 | INTRODUCTION}

During the 20th century, the whaling industry's overexploitation of large whales led to precipitous declines in many populations (Tulloch, Plagányi, Matear, Brown, \& Richardson, 2018; Whitehead \& Hooker, 2012). Many baleen whale populations are still listed as Endangered under the International Union for Conservation of Nature's Red List, and most of the 22 beaked whale species are currently listed as Data Deficient. Although the majority of commercial whaling stopped after the International Whaling Commission's moratorium in 1989, direct threats to these species now include increased offshore infrastructure developments, fishing, and shipping traffic, which result in entanglement/entrapment in fishing gear and ship strikes (Thomas, Reeves, \& Brownell, 2016). For baleen whales specifically, which undertake long migrations between high-latitude feeding grounds and low-latitude breeding grounds (Lockyer, 2007), entanglement in fishing gear is now almost ubiquitous in some populations (Neilson, Straley, Gabriele, \& Hills, 2009; Robbins, Knowlton, \& Landry, 2015; van der Hoop, Corkeron, \& Moore, 2016). Baleen whales and beaked whales are also subject to the other cumulative effects of anthropogenic disturbance, such as contaminant exposure and noise pollution (Thomas et al., 2016). For example, beaked whales have been shown to perform dives that are, on average, the longest and deepest recorded of any marine mammal (Baird et al., 2006; Tyack, Johnson, Aguilar de Soto, Sturlese, \& Madsen, 2006), but adaptations in their behaviour and/or their physiology that allow them to perform such extreme dives appear to make them particularly susceptible to the harmful effects of anthropogenic noise. In fact, certain species have been shown to mass strand in conjunction with naval sonar activities (Balcomb \& Claridge, 2001; Frantzis, 1998; Jepson et al., 2003; Simmonds \& Lopez-Jurado, 1991). Finally, habitat quality degradation, as a result of the short- and long-term effects of climate change and ocean acidification on marine ecosystems, is also a significant threat to populations of these species worldwide (Thomas et al., 2016).

There is, therefore, an urgent need to assess the consequences of anthropogenic disturbance in these long-lived and particularly vulnerable cetaceans. Specifically, tools are required to estimate and better understand the energetic consequences of anthropogenic disturbance through changes in body condition that can impact population health and ultimately conservation status. Body condition in mammals can be defined in various ways, but the focus here is on nutritive condition quantified as the energy stores of an individual (Aguilar \& Borrell, 1990; Pitt, Larivière, \& Messier, 2006). The size of these energy stores reflects an individual's foraging effort and success, as well as their reproductive needs throughout their life cycle (Aguilar \& Borrell, 1990). Animals in poorer condition have smaller energy stores than those in better condition, and the size of these energy stores wil affect an individual's ability to resist infectious diseases, reproduce successfully, and survive periods of food shortage (Møller, Christe, Erritzøe, \& Mavarez, 1998; Verrier, Groscolas, Guinet, \& Arnould, 2011). Body condition affects an animal's behavioural patterns in relation to foraging strategies, predator avoidance, and migratory movements (Bêty, Gauthier, \& Giroux, 2003; Heithaus et al., 2007).
Overall, body condition is a good predictor of fitness by affecting both survival and reproductive success (Hall, McConnell, \& Barker, 2001; Lockyer, 1986; Pitcher, Calkins, \& Pendleton, 1998; Pomeroy, Fedak, Rothery, \& Anderson, 1999; Williams et al., 2013).

Fats (lipids), specifically triacylglycerols (esters made up of a glycerol and three fatty acids), are more energy dense, and therefore take up less space than carbohydrates and proteins, which makes them the favoured energy storage form in mammals (Coleman \& Lee, 2004; Young, 1976). Adipose tissue lipid content has therefore been linked with total energy reserves and body condition in a range of mammalian species (Beck, Smith, \& Hammill, 1993; Shier \& Schemmel, 1975; Stirling, Thiemann, \& Richardson, 2008). When coupled with demographic and ecological data, using adipose tissue lipid content as a body condition index can be a biologically relevant, relatively inexpensive, and rapidly assessed marker applicable on a broad scale (McKinney et al., 2014). Cetaceans have evolved atypical and widespread deposits of lipids as a thick, subcutaneous blubber layer (Pond, 1998). Blubber is the most important site of energy storage in cetaceans as lipids are mobilized in times of energetic need and nutritional stress, and then deposited when food is in excess (Iverson, 2009). As a result, the direct quantification of blubber lipid content in cetacean carcasses has been used as a metric of overall energy stores and body condition in mysticetes (Ackman, Hingley, Eaton, Logan, \& Odense, 1975; Aguilar \& Borrell, 1990; Konishi, 2006; Lockyer, 1986), and to a lesser extent in odontocetes (Evans, Hindell, \& Thiele, 2003; Gómez-Campos, Borrell, \& Aguilar, 2011; Montie et al., 2008; Read, 1990). The biochemical characteristics of blubber lipids have also been extensively studied (Ackman, Eaton, \& Jangaard, 1965; Litchfield et al., 1975; Lockyer, McConnell, \& Waters, 1985; Varanasi \& Malins, 1971), and two main lipid classes, triacylglycerols and wax esters, have been identified. The relative abundance of these two lipid classes varies between cetacean family groups, with wax esters dominating the blubber tissue of deep-diving species (Koopman, 2007).

The collection of blubber and skin samples through dart biopsy sampling has become a standard method of collecting tissue samples from live, large cetaceans since the 1990s (Hunt et al., 2013). Shallow-depth dart biopsy samples from the posterior dorsal area (visible above the water's surface when the animals dive) are most often collected using either a crossbow or a rifle with modified, hollow, stainless steel dart tips (Hunt et al., 2013). The collection of such biopsy samples offers an opportunity to investigate markers of health and overall body condition to use as important population monitoring tools. However, the validation of lipid content analyses in cetacean blubber biopsy samples relative to accepted condition indices has not been fully evaluated. It is therefore important to understand the potential variability in blubber lipid content in order to correctly interpret the results from blubber samples collected by biopsy dart from live animals.

Full-depth dorsal blubber samples were collected from stranded, dead individuals from two cetacean families: ziphiids (beaked whales) and balaenopterids (one of the two families of baleen whales). The aim was to assess whether blubber lipid content obtained through biopsy sampling provides a robust measure of overall body condition 
in these two groups of cetaceans with different life-history strategies that shape the function, structure, and chemical composition of their blubber. First, changes in lipid content through the full blubber depth were investigated to estimate the representativeness of shallow-depth biopsies. Remotely obtained biopsies are comparable only to the superficial outer layer of the samples taken here from stranded animals. Second, the relationships between blubber lipid content and other individual covariates, including morphometric body condition indices, causes of death, sex, species, and age class, were investigated to evaluate what information about individual energy stores can be gained from such analyses. The use of total lipid content in shallowdepth blubber biopsy samples as a potential tool to measure overall body condition in live animals from these two cetacean families was therefore evaluated. The ability to monitor individual body condition in this way could ultimately offer vital insights into population-level resilience to anthropogenic impacts and environmental change and enhance the ability to address critical population conservation issues.

\section{2 | METHODS}

\section{1 | Sample collection from stranded cetaceans}

Seventeen dead, stranded individuals, from two cetacean families, were sampled and are summarized in Table 1. These were ziphiids ( $n=8$ ), comprising Cuvier's beaked whales (Ziphius cavirostris), Sowerby's beaked whales (Mesoplodon bidens), and northern bottlenose whales (Hyperoodon ampullatus), and balaenopterids ( $n=9$ ), comprising minke whales (Balaenoptera acutorostrata) and humpback whales (Megaptera novaeangliae). These were all freshly dead animals that showed minimal signs of decomposition.

Of the 17 individuals, 15 were sampled by the Scottish Marine Animal Strandings Scheme (SMASS) between 2013 and 2015. For these animals, the cause of death (COD) was determined either by necropsy or based on visual observations of the carcass showing signs of trauma, disease, or emaciation. Two COD categories were generated. 'Acute' cases were individuals that died of an acute trauma

TABLE 1 Summary of the balaenopterid and ziphiid individuals used for full-depth blubber sample analysis.

\begin{tabular}{|llll|}
\hline Family & Species & Number & Source \\
\hline Balaenopteridae & $\begin{array}{c}\text { Minke whale (Balaenoptera } \\
\text { acutorostrata) } \\
\text { Humpback whale (Megaptera } \\
\text { novaeangliae) }\end{array}$ & 6 & $\begin{array}{r}\text { SMASS, } \\
\text { MICS }\end{array}$ \\
\hline Ziphiidae & $\begin{array}{r}\text { Sowerby's beaked whale } \\
\text { SMesoplodon bidens) } \\
\text { (Muvier's beaked whale } \\
\text { (Ziphius cavirostris) } \\
\text { Northern bottlenose whale } \\
\text { (Hyperoodon ampullatus) }\end{array}$ & 4 & SMASS \\
\hline
\end{tabular}

SMASS: Scottish Marine Animal Strandings Scheme; MICS: Mingan Island Cetacean Study. (bycatch and acute entanglement). 'Chronic' cases were individuals that died of general debilitation and a prolonged decline in their health either through infectious disease (parasitic, bacterial, viral, or mycotic infections), starvation (severely emaciated animals that died of starvation/hypothermia), or chronic injuries (e.g. chronic entanglement). For the ziphiids, five individuals were acute cases and three were chronic cases. For the balaenopterids, five individuals were acute COD cases and two were chronic. Measurements of length, girth, and blubber thickness proximal to the dorsal fin along the dorsal axis were taken (Kuiken \& Hartmann, 1991). Individuals were classed as adults or juveniles using the lengths at sexual maturity for each species based on published data (Hauksson, Víkingsson, Halldórsson, Ólafsdóttir, \& Sigurjónsson, 2011; Heyning, 2002; Hooker \& Baird, 1999; Mead, 1989; Whitehead, Gowans, Faucher, \& McCarrey, 1997).

The final two individuals were an adult female minke whale and an adult female humpback whale that dead stranded in the Gulf of St Lawrence, Canada, and were opportunistically sampled by the Mingan Island Cetacean Study (MICS) during their 2013 and 2010 summer field seasons respectively. No COD was confirmed for these animals, and morphometric measurements were not taken.

Approximately $2.5-5 \mathrm{~cm}^{2}$ blocks of full-depth blubber were collected from the dorsal area immediately caudal to the dorsal fin. This area was chosen to emulate the standard biopsy site from live animals. The entire blubber layer was sampled for all animals to include both the epidermis and some underlying muscle so as to recognize the orientation of the sample. The samples were wrapped in aluminium foil, placed individually in plastic containers, and frozen at $-20^{\circ} \mathrm{C}$ before further analysis.

\section{2 | Comparative morphometric dataset from stranded cetaceans}

To investigate where the study individuals lie in terms of their overall body condition in the distribution of a larger sample size of animals, the potential range in individual morphometric body condition estimates for both species groups was assessed using data collected by SMASS between 1991 and 2015. These data were from 51 balaenopterids from four species (minke, humpback, fin [Balaenoptera physalus] and sei whales [Balaenoptera borealis]), and 42 ziphiids from four species (northern bottlenose whales, Sowerby's, Cuvier's, and Blainville's beaked whales [Mesoplodon densirostris]), where girth and length had been measured.

\section{3 | Lipid extraction}

The thickness of the fresh blubber samples was measured to the nearest millimetre as the length from the interface between the skin and the blubber to the interface between the blubber and the muscle (Figure 1). Any freezer-burn edges with a dark yellowish colour were removed and discarded. To reduce the loss of lipid while the samples were being prepared, the blubber was subsampled while still partially frozen. A full-depth subsample of the original block was cut and the 


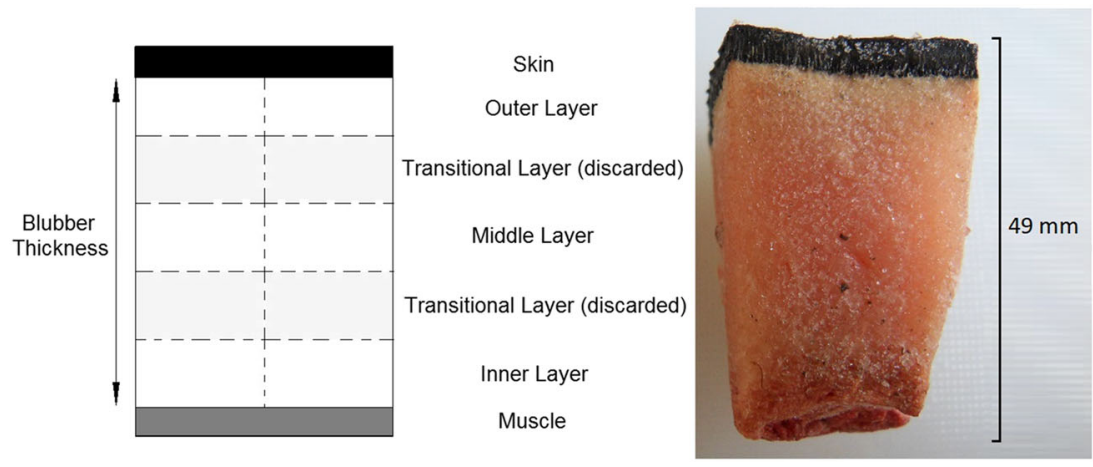

FIGURE 1 Subsampling of the full-depth blubber samples $>30 \mathrm{~mm}$ for lipid extraction. The diagram on the left indicates how the fulldepth samples were divided. The vertical dashed line shows where the blubber was cut in half to generate duplicate subsamples. The horizontal dashed lines show where the blubber was cut such that the outer, middle, and inner layers were retained for analysis while the two transitional layers were discarded. The photograph on the right shows a frozen full-depth blubber sample from a juvenile humpback whale before any subsampling took place

epidermis and muscle tissue removed. Whereas visible layering was apparent in the blubber of some samples, others did not show visible differences through the blubber depth. For this reason, the blubber was not divided according to visually discernible characteristics but was subdivided into layers of approximately equal thickness. For samples over $30 \mathrm{~mm}$ in depth, the blubber thickness was sufficient to allow its subdivision into five layers of equal thickness (Figure 1). The inner layer (adjacent to the muscle), the middle layer, and the outer layer (adjacent to the epidermis) were used for lipid extraction and the two transitional layers were discarded (Figure 1). Samples less than $30 \mathrm{~mm}$ in depth were not of sufficient thickness to follow this same protocol and so were divided into thirds and each layer was used for lipid extraction. Duplicate subsamples, each weighing between 0.15 and $0.3 \mathrm{~g}$, were taken from the full blubber depth as well as the inner, middle, and outer layers, and lipid was independently extracted from each of the blubber samples using a modified version of a previously published protocol (Folch, Lees, \& Stanley, 1957).

\section{4 | Statistical analysis}

The data from the ziphiids and balaenopterids were analysed separately. Two different statistical approaches were used: one to investigate differences in the distribution of total lipid content through blubber depth, and a second to investigate what other factors may be affecting blubber lipid content, including blubber thickness, sex, species, age class, COD, and morphometric body condition (girth/length).

All statistical analyses were performed using the statistical package, $R$, version 3.1.2 ( $R$ Core Team, 2014). The main challenges for analysing these data were that multiple lipid content measurements came from the same individuals, and these data did not have a normal distribution. The modelling approach used here takes advantage of the statistical structure of generalized linear mixed-effect models (GLMMs). GLMMs combine the properties of two statistical frameworks: linear mixed models, which are able to incorporate both fixed and random effects, and generalized linear models (GLMs), which are typically used for non-normal data (Bolker et al., 2008). Random effects can encompass variation among individuals when multiple responses are measured per individual. For this reason, GLMMs were used here first to investigate lipid content through the blubber depth whilst accounting for the repeated measurements from the same individuals. A GLMM (gImer function in the package Ime4) with a gamma distribution, a log link function, and individual as a random effect was used to investigate the effect of blubber layer (full, outer, middle, inner) on the lipid content of the samples from each species group.

GLMs were then used to investigate the effects of COD, blubber thickness, morphometric body condition (girth/length), sex, species, and age class on the blubber lipid content of the full-depth samples from each individual. GLMs with a gamma distribution and a log link function were used to better model the non-normal distribution of the lipid content data. All sampled individuals were used for the ziphiids $(n=8)$. However, for the balaenopterids, the two individuals sampled by MICS, for which COD and morphometric data were not available, were not included $(n=7)$.

For each species group, a GLM was generated to include the effects of all explanatory variables. To ensure that the explanatory variables were not correlated, and thus to avoid multicollinearity in the final model, variables were selected for inclusion based on variance inflation factors (VIFs). VIFs measure how much the variance of an estimated regression coefficient increases if the predictors are correlated. Starting with the full model, the VIF for each covariate in the model was calculated (car package). The covariate with the highest VIF value was removed from the model in a stepwise fashion until the VIF values for all covariates were $<3$ (Zuur, leno, \& Elphick, 2010). These covariates were retained for further analyses. Then, the 'dredge' model selection function (MuMln package) was used to identify from this subset of uncorrelated variables which ones best explain the variation in blubber lipid content data and should be included in the final model. The dredge function is a backwards selection tool that runs models with all possible combinations of the explanatory variables, including both the specified interactions between variables and their respective main effects. The goodness of fit of each model was assessed using the second-order Akaike information criterion (AICC), which uses a correction for small sample sizes. The models were ranked by their AICc to determine which combination of variables best explains the relationships in the data. The model 
with the lowest AICc value was used for further interpretation, as this contained only the variables and/or interactions of importance. Summary statistics of the model coefficients were used to assess the effect of each covariate on blubber lipid content.

\section{3 | RESULTS}

\section{1 | GLMM for variation through blubber depth}

The ziphiids showed very little variation in total lipid content, with a factor of just 1.6 difference between the highest and lowest measurements (full dataset range from $51.30 \pm 0.4 \%$ to $84.06 \pm 1.1 \%$ ), and no differences between the outer layer and the other layers (Figure 2a). The balaenopterids showed significant variation in blubber lipid content both within and between individuals, with a factor of 32.3 difference between the lowest and the highest measurements (full dataset range from $2.40 \pm 0.3 \%$ to $77.55 \pm 0.2 \%$ ), and significant differences between all blubber layers (Figure $2 \mathrm{~b}$ ). The outer layer had the highest lipid content and the inner layer had the lowest (Figure 2b). The lipid content was significantly higher in the full-depth sample compared with the inner layer, but significantly lower than the outer layer $(P<0.005)$. Interestingly, though there was much higher variation in the lipid content in the balaenopterids, the range in morphometric body condition estimates were similar between the two groups, with a factor of 1.5 and 1.7 difference between the thinnest and fattest ziphiids and balaenopterids respectively (ziphiid girth/length range 0.39-0.61; balaenopterid girth/length range 0.29-0.49) (Figure 3e-h).

There was no overall increase or decrease in the extraction variability, quantified as the measurement standard error between duplicate samples extracted in tandem, with increasing lipid content (linear model: Adjusted $R^{2}=0.01, P=0.15$ ), confirming that this lipid extraction method is appropriate for the range of sample masses analysed here. There were also no differences in the measurement error between the different blubber layers (ANOVA: $d f=3$, $F=1.786, P=0.154)$.

\subsection{GLM for variation with other covariates}

The lipid content in the full-depth blubber samples was not correlated with blubber thickness for either of the species groups (dorsal blubber layer mean thicknesses were $53.25 \pm 7.56 \mathrm{~mm}$ and $37.0 \pm 5.57 \mathrm{~mm}$ for the ziphiids and the balaenopterids respectively). No covariates were retained following GLM selection for the ziphiids, indicating that sex, age class, COD, and morphometric body condition (girth/length) did not contribute to the explanation of the variability in the blubber lipid content of these full-depth dorsal samples. This lack of correlation between lipid content measurements and other covariates of interest could have been a result of the small sample size of individuals. It is possible that only a small number of animals in either good or poor condition were sampled here. However, when compared with the larger morphometric dataset, the individuals sampled for lipid extraction covered a large part of this range for the ziphiids (Figure 3e,f). In fact, the full morphometric dataset collected by SMASS showed that there was less than a factor of two difference between the thinnest animal in the poorest condition and the fattest animal in the best condition (girth/length range between 0.37-0.63), indicating a very narrow range in apparent body condition in these species. Thus, the absence of any correlations between blubber lipid content, morphometric condition, and other covariates of interest is probably not a result of the sample size or a bias in the sampled individuals.

The best-fitting GLM for the balaenopterid data included only COD as an important explanatory variable, with a significantly lower lipid content in the chronic cases compared with the acute cases $(P=0.004 ;$ GLM: $d f=3$, weight $=0.87, \Delta$ AICc of 4.18 to the next best-fitting model; Table 2). In fact, individuals that died as a result of an acute trauma had significantly higher blubber lipid content
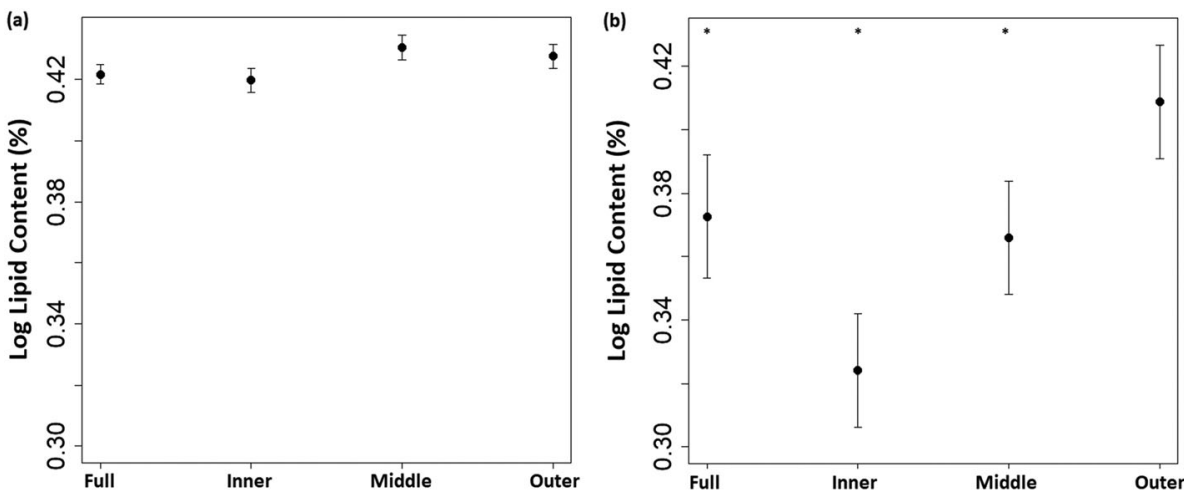

FIGURE 2 Final generalized linear mixed-effect model (GLMM) parameter estimates with associated error for total lipid content through the blubber depth. Note estimates are on a logarithmic scale as the GLMM uses a log link function, and both plots are on the same scale for comparison between families. (a) Ziphiids: Model selection did not retain layer as an important explanatory variable as there were no significant differences in lipid content between layers. (b) Balaenopterids: There were significant differences (indicated by *) between the outer layer and all other layers 


\section{Ziphiids}
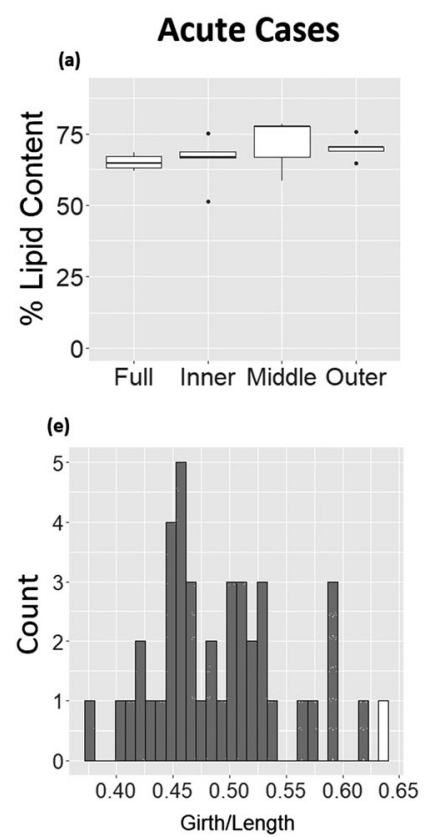

(b)

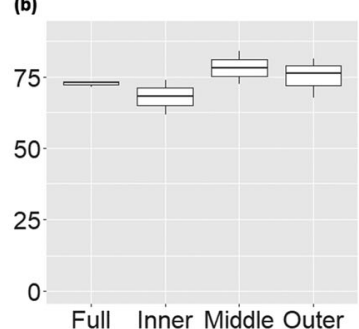

(f)

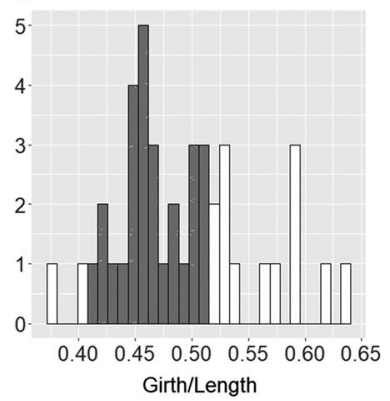

Balaenopterids
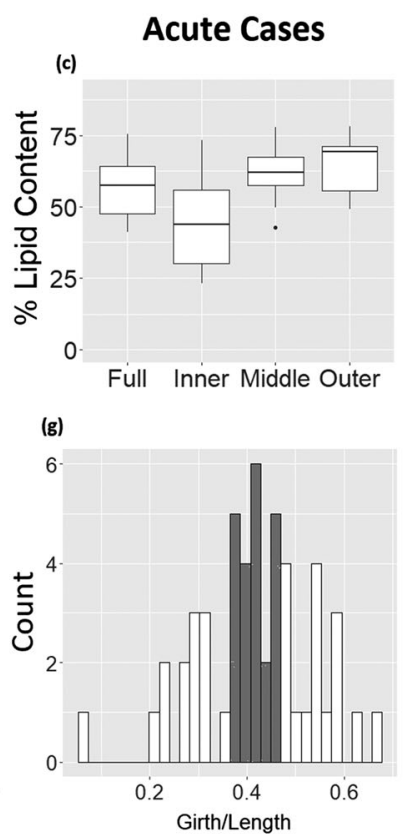

Chronic Cases

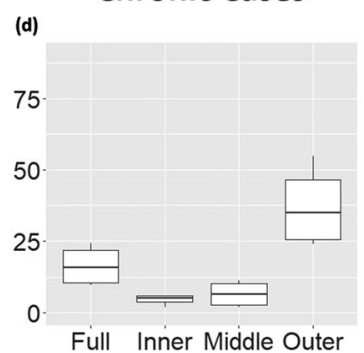

(h)

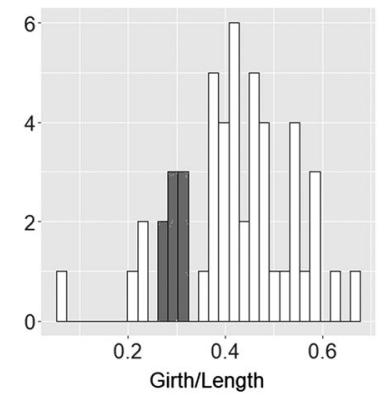

FIGURE 3 Boxplots of lipid content across blubber layers by cause of death category with histograms of the body condition estimates of the sampled animals compared with the full morphometric dataset collected by the Scottish Marine Animal Strandings Scheme (SMASS). (a, b) There was no difference in total lipid content between layers in the acute or chronic cases for the ziphiids. (c, d) Lipid content was significantly lower across all blubber layers in the chronic compared with the acute cases (ANOVA; $F=44.71, d f=1, P<0.0001$ ) in the balaenopterids. (e-h) Girth/length histograms for the for ziphiid $(n=42)$ and the balaenopterid $(n=51)$ data collected by SMASS. The shaded bars indicate the range in condition indices of the individuals sampled for blubber lipid extraction

TABLE 2 Summary table of the generalized linear mixed-effect model (GLMM) results, and the generalized linear model (GLM) results investigating the effects of various covariates on blubber lipid content for the two species groups

$\begin{array}{llll} & & \text { Ziphiids } n=8 & \text { Balaenopterids } n=7 \\ \text { GLMM } & \text { Covariates retained following model selection } & \text { None } & \text { Blubber layer }^{\mathrm{a}} \\ \text { GLM } & \begin{array}{l}\text { Covariates discarded based on VIFs } \\ \text { Covariates retained following model selection }\end{array} & \text { Sex, age class } & \text { Girth/length } \\ & \text { COD } & \text { None } & \text { COD }^{\mathrm{a}}\end{array}$

COD: cause of death; VIF: variable inflation factor.

The variable was retained after model selection and was statistically significant at the $5 \%$ level.

${ }^{b}$ VIFs measure collinearity between predictor variables. The predictor variables with high VIFs were excluded from the analysis.

across all layers than those with a chronic COD (ANOVA: $F=44.71$ $d f=1, P<0.0001$; Figure $3 c, d)$. The acute cases had higher girth/length estimates than the chronic cases (Figure 3g,h), even though they covered a much smaller range of the potential variation measured in the full morphometric dataset for these species collected by SMASS. In the full dataset, there was a 10-fold difference between the balaenopterids in the thinnest and the fattest condition (girth/length range between 0.064 and 0.67 ).

The effect of morphometric body condition was not retained as an important explanatory variable in the full-depth lipid content models for either species group. The relationship between the lipid content of each layer and morphometric body condition was then assessed separately. For the balaenopterids only, there was a significant positive correlation between lipid content and girth/length in the middle blubber layer alone (linear model: $P=0.035$, Adjusted $R^{2}=0.6$ ) (Figure 4).

\section{4 | DISCUSSION}

\section{1 | Lipid content stratification through blubber depth: Implications for biopsy sampling?}

Stratification of lipid content through blubber depth was only seen in the balaenopterids. The middle and inner layers had a lower lipid content than the outer layer closest to the skin, with the inner layer 
(a)

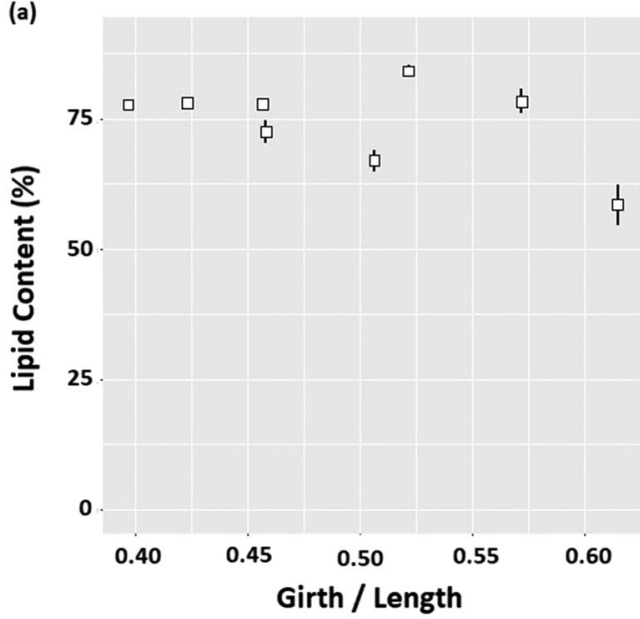

(b)

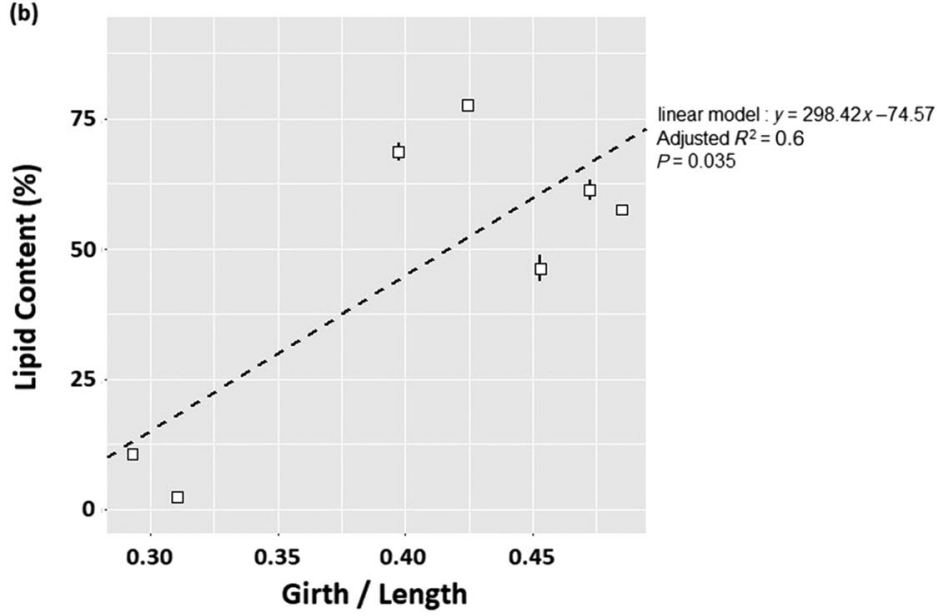

FIGURE 4 Lipid content in the middle blubber layer plotted against the morphometric body condition estimates for each species group. (a) Ziphiids: There was no correlation between the lipid content in the middle layer and girth/length. (b) Balaenopterids: There was a significant positive correlation between the lipid content in the middle layer and girth/length $\left(P=0.035\right.$, Adjusted $\left.R^{2}=0.6\right)$

showing the lowest lipid content overall. The stratification observed here is likely the result of differential metabolism of fatty acids, and thus of deposition and mobilization of lipid stores through the blubber depth (Lockyer, McConnell, \& Waters, 1984; Samuel \& Worthy, 2004; Smith \& Worthy, 2006). Long-chain polyunsaturated fatty acids of dietary origin are present in higher concentrations in the inner layer than in the outer layer, and these are preferentially metabolized due to their proximity to the body core (Koopman, Iverson, \& Gaskin, 1996; Krahn et al., 2004; Lockyer et al., 1984). This makes the inner and middle layers more metabolically active in terms of lipolysis and lipogenesis compared with the outermost layer, which is made up primarily of short-chain monosaturated fatty acids (Olsen \& Grahl-Nielsen, 2003; Ruchonnet, Boutoute, Guinet, \& Mayzaud, 2006; Samuel \& Worthy, 2004). The outer layer therefore likely has a more structural, and possibly thermoregulatory, role with a more stable composition over time as it is more metabolically inert (Koopman, Pabst, McLellan, Dillaman, \& Read, 2002). Therefore, had shallow biopsy samples been taken from the animals sampled here, they would provide inflated estimates of blubber lipid content as the outermost layer did not reflect the lipid available for mobilization in the middle and inner layers. Total lipid content in shallow-depth biopsies from balaenopterids is therefore not representative of an individual's lipid energy stores through the full blubber depth.

In contrast, the ziphiids showed no variation in blubber lipid content between the different layers. Blubber lipids in ziphiids are dominated by wax esters instead of triacylglycerols (Koopman, 2007; Litchfield, Greenberg, \& Mead, 1976; Singleton et al., 2017), and this different composition of the tissue probably affects the patterns of lipid deposition and mobilization. Although the blubber of ziphiids has been shown to display stratification of wax esters, the overall lipid content appears to be uniform (Koopman, 2007; Litchfield et al., 1976; Singleton et al., 2017). So, had shallow biopsy samples been taken from these animals the lipid content estimates would be representative of the total lipid across all layers. However, as ziphiid blubber does not show the same layered lipid deposition and mobilization characteristics seen in other cetacean species, it suggests that the tissue is perhaps not being used in the same way.

\section{2 | Lipid content variation as an indicator of body condition: Is it a useful marker?}

The wide variation in lipid content both within and between the balaenopterid samples is likely a result of the life-history strategies of these species. Balaenopterids cycle their energy stores during seasonal migrations that link temporally and spatially separated breeding and feeding seasons (Koopman, 2007). As they are adapted to cycle their fat stores, the range in blubber lipid content is likely to vary much more than for species that do not undertake prolonged fasting periods, and thus live within much narrower limits of stored energy reserves. This was highlighted in the larger dataset of morphometric measures from SMASS with the 10-fold difference between the girth/length index of individuals in the thinnest and fattest condition. COD was retained following model selection, showing that individuals that died as a result of acute trauma had a higher lipid content across the full blubber depth than chronically debilitated animals. This is to be expected, as chronically debilitated animals have depleted their fat reserves following a more gradual decline in health and perhaps reduced foraging opportunities compared with individuals that died as a result of an acute traumatic event.

Neither sex nor age class were retained as important explanatory variables, which was surprising given previous evidence of variation in fat stores across sex and reproductive classes in balaenopterids (Aguilar \& Borrell, 1990; Lockyer et al., 1985). However, these data were dominated by juvenile minke whales; for this reason, little can be inferred about the effect of age class on blubber lipid content. Similarly, as the animals had probably not reached sexual maturity, the lack of differences between the sexes could indicate that sex differences only appear once animals start to deposit and mobilize fat stores 
associated with the costs of reproduction. Finally, although the ful blubber depth samples could be used to differentiate between gross differences as a result of different COD categories, only the lipid content of the middle layer was significantly correlated with morphometric body condition. This is consistent with previous reports that the middle layer of fin and sei whale blubber is made of loose, fatty tissue, and was the most variable in thickness across individuals compared with the other two layers (Lockyer et al., 1985). The lack of correlation between the outer layer lipid content and morphometric condition further highlights that total lipid content in shallow-depth biopsy samples does not provide information on individual body condition in these species.

Model selection for the ziphiid data retained no covariates as important explanatory variables. There were also no significant correlations between the lipid content in any blubber layer and morphometric condition. Total lipid content from biopsy samples in these species, therefore, provides no information on individual body condition. One potential reason for the lack of variation seen here could be a consequence of the dorsal site of the blubber sample. Dorsal blubber samples were taken immediately caudal to the dorsal fin in order to investigate the potential use of biopsy samples that target this area of free-ranging animals. Whaling data and strandings data have provided valuable physiological information about topographical variation in blubber lipid stores in both the large mysticetes and small odonotocetes. To date, however, there have been no such studies to investigate the variation in ziphiids, a much less well-understood family of cetaceans. The posterior dorsal area of mysticetes is a major site for lipid storage in both the blubber and the muscle (Lockyer et al., 1985), but this may not be the case for beaked whales, particularly if they are more similar to small odontocetes. In small odontocetes, the blubber in the thoracic-abdominal region is hypothesized to play an important role in insulation and energy storage, whereas the region posterior to the dorsal fin is thought to primarily act to maintain hydrodynamic and locomotory functions and is metabolically inert (Gómez-Campos, Borrell, Correas, \& Aguilar, 2015; Koopman, 1998; Koopman et al., 2002; Tornero, Borrell, Forcada, Pubill, \& Aguilar, 2004).

Some areas of the body are therefore more important for energy storage than others, and this variation is not necessarily captured in the dorsal sampling site of biopsy samples for some species. An important next step is to analyse the blubber lipid content across multiple sample sites in ziphiids to assess if their patterns of lipid stores are more similar to those observed in large mysticetes or small odontocetes. This would help to determine if the lack of relationship between lipid content and metrics of body condition and other covariates of interest used here is a result of the dorsal sampling site. Or perhaps, ziphiid blubber does not act as an energy storage organ with clear patterns of lipid deposition and mobilization in the same way as other cetacean species.

The apparent absence of variation in total lipid content both within and between the ziphiids could also be a result of the high wax ester content of the blubber (Hooker, Iverson, Ostrom, \& Smith, 2001; Koopman, 2007; Litchfield et al., 1976; Singleton et al., 2017). It is possible that ziphiid blubber lipid storage properties differ from other species because wax esters have different chemical properties to the triacylglycerols. For example, wax esters are less rapidly metabolized and less efficiently hydrolysed than triacylglycerols (Place, 1992; Pond, 1998), which makes them poor energy reserves. Wax esters also have lower densities (specific gravities) than triacylglycerols (Sargent, 1978), and they are less sensitive to phase change with changing temperature (Nevenzel, 1970), both of which affect overall tissue buoyancy. Wax esters in the blubber have also been suggested to play a potentially important role in thermoregulation as they provide better insulation than triacylglycerols (Bagge, Koopman, Rommel, McLellan, \& Pabst, 2012; Singleton et al., 2017). So, stores of wax esters may provide various elements of physiological or mechanical advantage in terms of buoyancy and insulation that contribute to their extreme deep-diving abilities. Currently, there is no evidence to suggest that any of the beaked whale species experience substantial or predictable fasting cycles, or periods of food shortage when lipid reserves might be drawn upon (MacLeod, 2018). These species may therefore prioritize maintaining consistent blubber hydrodynamic, thermal, and buoyancy parameters, which comes at the expense of having variable fat deposits for energy storage. As such, small changes in the blubber lipid content may considerably affect their overall buoyancy and diving capabilities, so they exist within a small range (Miller et al., 2016). The very narrow range in the girth/length condition estimates using the larger morphometric dataset from SMASS further supports the possibility that these species survive within very narrow body fat limits.

\section{3 | Cetacean blubber: Much more than just an energy store}

There was no relationship between blubber thickness and blubber lipid content in either species group. The results of this study, therefore, support the idea that blubber thickness alone is an inadequate index of fat stores as the lipid content of the tissue varies independently of its thickness (Aguilar, Borrell, \& Gomez-Campos, 2007; Dunkin, McLellan, Blum, \& Pabst, 2005; Evans et al., 2003). There are two possible reasons for this lack of a relationship: Either the small sample size of this dataset prevented the detection of any correlations between lipid content and blubber thickness, or the other functional roles of the blubber not involved in energy storage also affect blubber thickness. This is a small sample size of 17 individuals, and it is possible that the lack of correlation between lipid content and blubber thickness could be because there was not a great enough range in blubber thicknesses or lipid content within each species group. However, as the ziphiids sampled covered the range of potential morphometric body condition estimates from the larger SMASS dataset, and the balaenopterid samples showed a huge range in lipid content from $\sim 2 \%$ to $\sim 76 \%$, this is probably not the case.

Various other studies have also shown that blubber thickness was a poor index of nutritive condition, as it was not correlated with changes in overall body fat reserves (Aguilar et al., 2007; Caon, Fialho, 
\& Danilewicz, 2007; Evans et al., 2003; Gómez-Campos et al., 2015; Koopman, 2007; Read, 1990; Ruchonnet et al., 2006). It is well recognized across all species that blubber, in addition to its role as a deposit of energy, serves important functions as an insulator, it is involved in active thermoregulation, it streamlines the body, facilitates hydrodynamic locomotion, contributes to water balance, and provides buoyancy (Iverson, 2009). As such, the extent to which blubber lipids can be mobilized is limited by these other functional considerations. For this reason, attempts should be made to move away from using blubber thickness and total blubber lipid content as an indicator of condition, and alternative methods should be investigated across all species. There are likely very complex relationships between body size, thermal habitat, lipid stratification, blubber thickness, and metabolism that warrant further investigation.

\subsection{Conclusions and future directions}

Total lipid content measured in shallow-depth blubber biopsy samples from the dorsal area in balaenopterids and ziphiids is not a useful tool to estimate overall body condition. In balaenopterids, it provides no information on the lipid energy reserves in the middle and inner layers that are involved in lipid deposition and mobilization. In ziphiids, it shows no variation between individuals to distinguish between animals in either good or poor health. Varying habitats and life-history strategies have shaped blubber composition characteristics, which likely result in the species-specific differences in lipid content seen here. The relative importance of different blubber functions across different species also means that if the ecology, and hence physiology, of a species requires stability to be maintained in one blubber function, it will influence the variability possible in others. As a result, quantifying total lipid alone from biopsy samples obtained from live animals provides little information on an individual's overall health or energy reserves. In addition, a number of studies have now shown that the lipid content measured in a biopsy sample is not reflective of that of the tissue when sampled at necropsy (Krahn et al., 2004; McKinney et al., 2014; Ryan, McHugh, O'Connor, \& Berrow, 2012). The discrepancies are thought to be a result of lipid loss during dart retrieval as the adipocytes are disrupted upon dart impact.

Further work should prioritize measuring other components of blubber biopsies as potential markers of condition. For example, blubber cellularity, specifically adipocyte size and number, shows some potential as a biomarker of adiposity (Castrillon, Huston, \& Bengtson Nash, 2017). Using the proportions of different saturated/unsaturated fatty acids or the proportion of triaclyglycerols to wax esters, for example, could also be investigated as a more reliable marker. Proteomic and transcriptomic approaches to examine changes in proteins of interest and the use of gene expression profiles in blubber tissue are also being investigated to identify important markers and regulators of lipid metabolism and energy homeostasis (Kershaw, Botting, Brownlow, \& Hall, 2018; Khudyakov, Champagne, Meneghetti, \& Crocker, 2017; Martinez et al., 2018).
Finally, as well as using biomarkers to estimate the energy reserves of individuals through biopsy sampling, morphometric measurements using photogrammetry are also a potentially valuable tool for body condition estimates in some species. The use of unmanned aerial vehicles to obtain full-body aerial images of individuals has recently made aerial photogrammetry techniques much more accessible (Durban et al., 2016; Durban, Fearnbach, Barrett-Lennard, Perryman, \& Leroi, 2015). A small number of studies have used high-resolution images collected from unmanned aerial vehicles to investigate populationlevel changes in body condition (Christiansen et al., 2018; Christiansen, Dujon, Sprogis, Arnould, \& Bejder, 2016; Fearnbach, Durban, Ellifrit, \& Balcomb, 2018). By combining new methods in blubber biomarker research and aerial photogrammetry, better measures of the health of individuals will be developed as tools for integration into long-term monitoring protocols for populations. Tracking the health and overall body condition of free-ranging cetaceans in this way is important for assessing the impacts of anthropogenic disturbance on these species. This will help identify populations that are particularly at risk, which is crucial for driving population conservation efforts and priorities.

\section{ACKNOWLEDGEMENTS}

We would like to thank Nick Davison, Mariel ten Doeschate, Alicia Coupe, and Barry McGovern from SMASS, as well as the team members and volunteers from MICS for the collection of blubber samples from the stranded animals. We would like to thank the funders: the Department for Environment Food and Rural Affairs and Marine Scotland, for a number of long-term monitoring contracts awarded to SMASS, the Sea Mammal Research Unit National Capability Funding from the Natural Environment Research Council (grant no. SMRU 10001), and the Strategic Environmental Research and Development Program (award RC-2337).

\section{ORCID}

Joanna L. Kershaw (D) https://orcid.org/0000-0003-2244-3198

Patrick J.O. Miller (D) https://orcid.org/0000-0001-8028-9673

Ailsa J. Hall (D) https://orcid.org/0000-0002-7562-1771

\section{REFERENCES}

Ackman, R. G., Eaton, C. A., \& Jangaard, P. M. (1965). Lipids of the fin whale (Balaenoptera physalus) from North Atlantic waters: Fatty acid composition of whole blubber and blubber sections. Canadian Journal of Biochemistry, 43, 1513-1520. https://doi.org/10.1139/o65-169

Ackman, R. G., Hingley, J. H., Eaton, C. A., Logan, V. H., \& Odense, P. H. (1975). Layering and tissue composition in the blubber of the northwest Atlantic sei whale (Balaenoptera borealis). Canadian Journal of Zoology, 53, 1340-1344. https://doi.org/10.1139/z75-159

Aguilar, A., \& Borrell, A. (1990). Patterns of lipid content and stratification in the blubber of fin whales (Balaenoptera physalus). Journal of Mammalogy, 71, 544-554. https://doi.org/10.2307/1381793

Aguilar, A., Borrell, A., \& Gómez-Campos, E. (2007). The reliability of blubber thickness as a measure of body condition in large whales. Paper presented at the 59th Annual Meeting of the Scientific Committee of the International Whaling Commission (Cambridge, UK) (SC/59/O17). 
Bagge, L. E., Koopman, H. N., Rommel, S. A., McLellan, W. A., \& Pabst, D. A. (2012). Lipid class and depth-specific thermal properties in the blubber of the short-finned pilot whale and the pygmy sperm whale. The Journal of Experimental Biology, 215, 4330-4339. https://doi.org/ 10.1242/jeb.071530

Baird, R. W., Webster, D. L., McSweeney, D. J., Ligon, A. D., Schorr, G. S., \& Barlow, J. (2006). Diving behaviour of Cuvier's (Ziphius cavirostris) and Blainville's (Mesoplodon densirostris) beaked whales in Hawai'i. Canadian Journal of Zoology, 84, 1120-1128. https://doi.org/10.1139/z06-095

Balcomb, K. C., \& Claridge, D. E. (2001). A mass stranding of cetaceans caused by naval sonar in the Bahamas. Bahamas Journal of Science, 8 , 1-12.

Beck, G. G., Smith, T. G., \& Hammill, M. O. (1993). Evaluation of body condition in the Northwest Atlantic harp seal (Phoca groenlandica). Canadian Journal of Fisheries and Aquatic Sciences, 50, 1372-1381. https://doi.org/10.1139/f93-157

Bêty, J., Gauthier, G., \& Giroux, J. (2003). Body condition, migration, and timing of reproduction in snow geese: A test of the conditiondependent model of optimal clutch size. American Naturalist, 162, 110-121. https://doi.org/10.1086/375680

Bolker, B. M., Brooks, M. E., Clark, C. J., Geange, S. W., Poulsen, J. R., Stevens, M. H. H., \& White, J.-S. S. (2008). Generalized linear mixed models: A practical guide for ecology and evolution. Trends in Ecology \& Evolution, 24, 127-135. https://doi.org/10.1016/j.tree.2008.10.008

Caon, G., Fialho, C. B., \& Danilewicz, D. (2007). Body fat condition in franciscanas (Pontoporia blainvillei) in Rio Grande do Sul, southern Brazil. Journal of Mammalogy, 88, 1335-1341. https://doi.org/ 10.1644/06-mamm-a-364r.1

Castrillon, J., Huston, W., \& Bengtson Nash, S. (2017). The blubber adipocyte index: A nondestructive biomarker of adiposity in humpback whales (Megaptera novaeangliae). Ecology and Evolution, 7, 5131-5139. https://doi.org/10.1002/ece3.2913

Christiansen, F., Dujon, A. M., Sprogis, K. R., Arnould, J. P. Y., \& Bejder, L. (2016). Noninvasive unmanned aerial vehicle provides estimates of the energetic cost of reproduction in humpback whales. Ecosphere, 7 , e01468. https://doi.org/10.1002/ecs2.1468

Christiansen, F., Vivier, F., Charlton, C., Ward, R., Amerson, A., Burnell, S., \& Bejder, L. (2018). Maternal body size and condition determine calf growth rates in southern right whales. Marine Ecology Progress Series, 592, 267-281. https://doi.org/10.3354/meps12522

Coleman, R. A., \& Lee, D. P. (2004). Enzymes of triacylglycerol synthesis and their regulation. Progress in Lipid Research, 43, 134-176. https:// doi.org/10.1016/S0163-7827(03)00051-1

Dunkin, R. C., McLellan, W. A., Blum, J. E., \& Pabst, D. A. (2005). The ontogenetic changes in the thermal properties of blubber from Atlantic bottlenose dolphin Tursiops truncatus. Journal of Experimental Biology, 208, 1469-1480. https://doi.org/10.1242/jeb.01559

Durban, J. W., Fearnbach, H., Barrett-Lennard, L. G., Perryman, W. L., \& Leroi, D. J. (2015). Photogrammetry of killer whales using a small hexacopter launched at sea. Journal of Unmanned Vehicle Systems, 3, 131-135. https://doi.org/10.1139/juvs-2015-0020

Durban, J. W., Moore, M. J., Chiang, G., Hickmott, L. S., Bocconcelli, A., Howes, G., ... LeRoi, D. J. (2016). Photogrammetry of blue whales with an unmanned hexacopter. Marine Mammal Science, 32, 1510-1515. https://doi.org/10.1111/mms.12328

Evans, K., Hindell, M. A., \& Thiele, D. (2003). Body fat and condition in sperm whales, Physeter macrocephalus, from southern Australian waters. Comparative Biochemistry and Physiology Part A: Molecular \& Integrative Physiology, 134, 847-862. https://doi.org/10.1016/S10956433(03)00045-X
Fearnbach, H., Durban, J. W., Ellifrit, D. K., \& Balcomb, K. C. (2018). Using aerial photogrammetry to detect changes in body condition of endangered southern resident killer whales. Endangered Species Research, 35, 175-180. https://doi.org/10.3354/esr00883

Folch, J., Lees, M., \& Stanley, G. H. S. (1957). A simple method for the isolation and purification of total lipides from animal tissues. Journal of Biological Chemistry, 226, 497-509.

Frantzis, A. (1998). Does acoustic testing strand whales? Nature, 392, 29. https://doi.org/10.1038/32068

Gómez-Campos, E., Borrell, A., \& Aguilar, A. (2011). Assessment of nutritional condition indices across reproductive states in the striped dolphin (Stenella coeruleoalba). Journal of Experimental Marine Biology and Ecology, 405, 18-24. https://doi.org/10.1016/j.jembe.2011.05.013

Gómez-Campos, E., Borrell, A., Correas, J., \& Aguilar, A. (2015). Topographical variation in lipid content and morphological structure of the blubber in the striped dolphin. Scientia Marina, 79, 189-197. https:// doi.org/10.3989/scimar.04093.25A

Hall, A. J., McConnell, B. J., \& Barker, R. J. (2001). Factors affecting firstyear survival in grey seals and their implications for life history strategy. Journal of Animal Ecology, 70, 138-149. https://doi.org/10.1111/ j.1365-2656.2001.00468.x

Hauksson, E., Víkingsson, G. A., Halldórsson, S. D., Ólafsdóttir, D., \& Sigurjónsson, J. (2011). Preliminary report on biological parameters for NA minke whales in Icelandic waters. Paper presented at the 63rd Annual Meeting of the International Whaling Commission, SC/63/ O15. https://iwc.int/sc63docs

Heithaus, M. R., Frid, A., Wirsing, A. J., Dill, L. M., Fourqurean, J. W., Burkholder, D., ... Bejder, L. (2007). State-dependent risk-taking by green sea turtles mediates top-down effects of tiger shark intimidation in a marine ecosystem. Journal of Animal Ecology, 76, 837-844. https:// doi.org/10.1111/j.1365-2656.2007.01260.x

Heyning, J. E. (2002). Cuvier's beaked whale. In W. F. Perrin, B. Wursig, \& J. G. M. Thewissen (Eds.), Encyclopedia of marine mammals (pp. 305-307). San Diego, CA: Academic Press.

Hooker, S. K., \& Baird, R. W. (1999). Observations of Sowerby's beaked whales, Mesoplodon bidens, in the Gully, Nova Scotia. Canadian Field Naturalist, 113, 273-277.

Hooker, S. K., Iverson, S. J., Ostrom, P., \& Smith, S. C. (2001). Diet of northern bottlenose whales inferred from fatty-acid and stable-isotope analyses of biopsy samples. Canadian Journal of Zoology, 79, 1442-1454. https://doi.org/10.1139/z01-096

Hunt, K. E., Moore, M. J., Rolland, R. M., Kellar, N. M., Hall, A. J., Kershaw, J. L., ... Kraus, S. D. (2013). Overcoming the challenges of studying conservation physiology in large whales: A review of available methods. Conservation Physiology, 1, cot006. https://doi.org/10.1093/conphys/ cot006

Iverson, S. J. (2009). Blubber. In W. F. Perrin, B. Würsig, \& J. G. M. Thewissen (Eds.), Encyclopedia of marine mammals (Second ed.). San Diego, CA: Academic Press.

Jepson, P. D., Arbelo, M., Deaville, R., Patterson, I. A. P., Castro, P., Baker, J. R., ... Fernández, A. (2003). Gas-bubble lesions in stranded cetaceans. Nature, 425, 575-576. https://doi.org/10.1038/425575a

Kershaw, J. L., Botting, C. H., Brownlow, A., \& Hall, A. J. (2018). Not just fat: Investigating the proteome of cetacean blubber tissue. Conservation Physiology, 6, coy003. https://doi.org/10.1093/conphys/coy003

Khudyakov, J. I., Champagne, C. D., Meneghetti, L. M., \& Crocker, D. E. (2017). Blubber transcriptome response to acute stress axis activation involves transient changes in adipogenesis and lipolysis in a fastingadapted marine mammal. Scientific Reports, 7, 42110. https://doi.org/ 10.1038/srep42110 
Konishi, K. (2006). Characteristics of blubber distribution and body condition indicators for Antarctic minke whales (Balaenoptera bonaerensis). Mammal Study, 31, 15-22. https://doi.org/10.3106/1348-6160(2006) 31[15:COBDAB]2.0.CO;2

Koopman, H. N. (1998). Topographical distribution of the blubber of harbour porpoises. Journal of Mammalogy, 79, 260-270. https://doi.org/ $10.2307 / 1382862$

Koopman, H. N. (2007). Phylogenetic, ecological, and ontogenetic factors influencing the biochemical structure of the blubber of odontocetes. Marine Biology, 151, 277-291. https://doi.org/10.1007/s00227-0060489-8

Koopman, H. N., Iverson, S. J., \& Gaskin, D. E. (1996). Stratification and age-related differences in blubber fatty acids of the male harbour porpoise (Phocoena phocoena). Journal of Comparative Physiology B, 165, 628-639. https://doi.org/10.1007/bf00301131

Koopman, H. N., Pabst, D. A., McLellan, W. A., Dillaman, R. M., \& Read, A. J. (2002). Changes in blubber distribution and morphology associated with starvation in the harbour porpoise (Phocoena phocoena): Evidence for regional differences in blubber structure and function. Physiological and Biochemical Zoology, 75, 498-512. https://doi.org/10.1086/ 342799

Krahn, M. M., Herman, D. P., Ylitalo, G. M., Sloan, C. A., Burrows, D. G., Hobbs, R. C., ... Moore, C. J. (2004). Stratification of lipids, fatty acids and organochlorine contaminants in blubber of white whales and killer whales. Journal of Cetacean Research Management, 6, 175-189.

Kuiken, T., \& Hartmann, M. G. (1991). Dissection techniques and tissue sampling. In T. Kuiken, \& M. G. Hartmann (Eds.), Proceedings of the first ECS workshop on cetacean pathology: Dissection techniques and tissue sampling: Leiden, the Netherlands, 13-14 September 1991 (Vol. 39). ECS Newsletter No. 17-Special Issue. Stralsund, Germany: European Cetacean Society.

Litchfield, C., Greenberg, A. J., Caldwell, D. K., Caldwell, M. C., Sipos, J. C., \& Ackman, R. G. (1975). Comparative lipid patterns in acoustical and nonacoustical fatty tissues of dolphins, porpoises and toothed whales. Comparative Biochemistry and Physiology Part B: Comparative Biochemistry, 50, 591-597. https://doi.org/10.1016/0305-0491(75)90095-4

Litchfield, C., Greenberg, A. J., \& Mead, J. G. (1976). The distinctive character of Ziphiidae head and blubber fats. Cetology, 23, 1-10.

Lockyer, C. H. (1986). Body fat condition in Northeast Atlantic fin whales, Balaenoptera physalus, and its relationship with reproduction and food resource. Canadian Journal of Fisheries and Aquatic Sciences, 43, 142-147. https://doi.org/10.1139/f86-015

Lockyer, C. H. (2007). All creatures great and smaller: A study in cetacean life history energetics. Journal of the Marine Biological Association of the United Kingdom, 87, 1035-1045. https://doi.org/10.1017/S00253 15407054720

Lockyer, C. H., McConnell, L. C., \& Waters, T. D. (1984). The biochemical composition of fin whale blubber. Canadian Journal of Zoology, 62, 2553-2562. https://doi.org/10.1139/z84-373

Lockyer, C. H., McConnell, L. C., \& Waters, T. D. (1985). Body condition in terms of anatomical and biochemical assessment of body fat in North Atlantic fin and sei whales. Canadian Journal of Zoology, 63, 2328-2338. https://doi.org/10.1139/z85-345

MacLeod, C. D. (2018). Beaked whales, overview. In B. Wursig, J. G. M. Thewissen, \& K. Kovacs (Eds.), Encyclopedia of marine mammals (3rd ed.). San Diego, CA: Academic Press.

Martinez, B., Khudyakov, J. I., Rutherford, K., Crocker, D. E., Gemmell, N., \& Ortiz, R. M. (2018). Adipose transcriptome analysis provides novel insights into molecular regulation of prolonged fasting in northern elephant seal pups. Physiological Genomics, 50, 495-503. https://doi.org/ 10.1152/physiolgenomics.00002.2018
McKinney, M. A., Atwood, T., Dietz, R., Sonne, C., Iverson, S. J., \& Peacock, E. (2014). Validation of adipose lipid content as a body condition index for polar bears. Ecology and Evolution, 4, 516-527. https://doi.org/ 10.1002/ece3.956

Mead, J. G. (1989). Beaked whales of the genus Mesoplodon. In S. H. Ridgway, \& R. Harrison (Eds.), Handbook of marine mammals: River dolphins and toothed whales (Vol. 4) (pp. 349-430). San Diego, CA: Academic Press.

Miller, P. J. O., Narazaki, T., Isojunno, S., Aoki, K., Smout, S. C., \& Sato, K. (2016). Body density and diving gas volume of the northern bottlenose whale (Hyperoodon ampullatus). The Journal of Experimental Biology, 219, 2458-2468. https://doi.org/10.1242/jeb.137349

Møller, A. P., Christe, P., Erritzøe, J., \& Mavarez, J. (1998). Condition, disease and immune defence. Oikos, 83, 301-306. https://doi.org/ $10.2307 / 3546841$

Montie, E. W., Garvin, S. R., Fair, P. A., Bossart, G. D., Mitchum, G. B., McFee, W. E., ... Hahn, M. E. (2008). Blubber morphology in wild bottlenose dolphins (Tursiops truncatus) from the southeastern United States: Influence of geographic location, age class, and reproductive state. Journal of Morphology, 269, 496-511. https://doi.org/10.1002/ jmor.10602

Neilson, J. L., Straley, J. M., Gabriele, C. M., \& Hills, S. (2009). Non-lethal entanglement of humpback whales (Megaptera novaeangliae) in fishing gear in northern Southeast Alaska. Journal of Biogeography, 36, 452-464. https://doi.org/10.1111/j.1365-2699.2007.01820.x

Nevenzel, J. C. (1970). Occurrence, function and biosynthesis of wax esters in marine organisms. Lipids, 5, 308-319. https://doi.org/ $10.1007 / \mathrm{bf0} 2531462$

Olsen, E., \& Grahl-Nielsen, O. (2003). Blubber fatty acids of minke whales: Stratification, population identification and relation to diet. Marine Biology, 142, 13-24. https://doi.org/10.1007/s00227-002-0934-2

Pitcher, K. W., Calkins, D. G., \& Pendleton, G. W. (1998). Reproductive performance of female Steller sea lions: An energetics-based reproductive strategy? Canadian Journal of Zoology, 76, 2075-2083. https://doi.org/ 10.1139/z98-149

Pitt, J. A., Larivière, S., \& Messier, F. (2006). Condition indices and bioelectrical impedance analysis to predict body condition of small carnivores. Journal of Mammalogy, 87, 717-722. https://doi.org/10.2307/ 4094598

Place, A. R. (1992). Comparative aspects of lipid digestion and absorption: Physiological correlates of wax ester digestion. American Journal of Physiology, 263, 464-471. https://doi.org/10.1152/ajpregu.1992. 263.3.R464

Pomeroy, P. P., Fedak, M. A., Rothery, P., \& Anderson, S. (1999). Consequences of maternal size for reproductive expenditure and pupping success of grey seals at North Rona, Scotland. Journal of Animal Ecology, 68, 235-253. https://doi.org/10.1046/j.1365-2656.1999. 00281.x

Pond, C. M. (1998). The fats of life. Cambridge, UK: Cambridge University Press. https://doi.org/10.1017/CBO9780511584633

R Core Team. (2014). R: A language and environment for statistical computing. Vienna, Austria: R Foundation for Statistical Computing. http:// www.R-project.org/

Read, A. J. (1990). Estimation of body condition in harbour porpoises, Phocoena phocoena. Canadian Journal of Zoology, 68, 1962-1966. https://doi.org/10.1139/z90-276

Robbins, J., Knowlton, A. R., \& Landry, S. (2015). Apparent survival of North Atlantic right whales after entanglement in fishing gear. Biological Conservation, 191, 421-427: https://doi.org/10.1016/j. biocon.2015.07.023 
Ruchonnet, D., Boutoute, M., Guinet, C., \& Mayzaud, P. (2006). Fatty acid composition of Mediterranean fin whale Balaenoptera physalus blubber with respect to body heterogeneity and trophic interaction. Marine Ecology Progress Series, 311, 165-174. https://doi.org/10.3354/ meps311165

Ryan, C., McHugh, B., O'Connor, I., \& Berrow, S. (2012). Lipid content of blubber biopsies is not representative of blubber in situ for fin whales (Balaenoptera physalus). Marine Mammal Science, 29, 542-547. https://doi.org/10.1111/j.1748-7692.2012.00578.x

Samuel, A. M., \& Worthy, G. A. J. (2004). Variability in fatty acid composition of bottlenose dolphin (Tursiops truncatus) blubber as a function of body site, season, and reproductive state. Canadian Journal of Zoology, 82, 1933-1942. https://doi.org/10.1139/z05-001

Sargent, J. R. (1978). Marine wax esters. Science Progress, 65, 437-458.

Shier, P. D., \& Schemmel, R. (1975). Effects of diet, age, strain and anatomical site on fat depot triglyceride and fatty acid content in rats. Proceedings of the Society for Experimental Biology and Medicine, 149, 864-870. https://doi.org/10.3181/00379727-149-38915

Simmonds, M. P., \& Lopez-Jurado, L. F. (1991). Whales and the military Nature, 351, 448. https://doi.org/10.1038/351448a0

Singleton, E. M., McLellan, W. A., Koopman, H. N., Pokorny, A., Scharf, F. S., \& Pabst, A. D. (2017). Lipid composition and thermal properties of the blubber of Gervais' beaked whale (Mesoplodon europaeus) across ontogeny. Marine Mammal Science, 33, 695-705. https://doi.org/ 10.1111/mms.12389

Smith, H. R., \& Worthy, G. A. J. (2006). Stratification and intra- and interspecific differences in fatty acid composition of common dolphin (Delphinus sp.) blubber: Implications for dietary analysis. Comparative Biochemistry and Physiology Part B: Biochemistry and Molecular Biology, 143, 486-499. https://doi.org/10.1016/j.cbpb.2005.12.025

Stirling, I., Thiemann, G. W., \& Richardson, E. (2008). Quantitative support for a subjective fatness index for immobilized polar bears. The Journal of Wildlife Management, 72, 568-574. https://doi.org/10.2193/2007123

Thomas, P. O., Reeves, R. R., \& Brownell, R. L. (2016). Status of the world's baleen whales. Marine Mammal Science, 32, 682-734. https://doi.org/ 10.1111/mms.12281

Tornero, V., Borrell, A., Forcada, J., Pubill, E., \& Aguilar, A. (2004). Retinoid and lipid patterns in the blubber of common dolphins (Delphinus delphis): Implications for monitoring vitamin A status. Comparative Biochemistry and Physiology Part B: Biochemistry and Molecular Biology, 137, 391-400. https://doi.org/10.1016/j.cbpc.2004.01.001

Tulloch, V. J. D., Plagányi, É. E., Matear, R., Brown, C. J., \& Richardson, A. J. (2018). Ecosystem modelling to quantify the impact of historical whaling on Southern Hemisphere baleen whales. Fish and Fisheries, 19, 117-137. https://doi.org/10.1111/faf.12241
Tyack, P. L., Johnson, M., Aguilar de Soto, N., Sturlese, A., \& Madsen, P. T. (2006). Extreme diving of beaked whales. Journal of Experimental Biology, 209, 4238-4253. https://doi.org/10.1242/jeb.02505

van der Hoop, J., Corkeron, P., \& Moore, M. (2016). Entanglement is a costly life-history stage in large whales. Ecology and Evolution, 7. 92-106. https://doi.org/10.1002/ece3.2615

Varanasi, U., \& Malins, D. C. (1971). Unique lipids of the porpoise (Tursiops gilli): Differences in triacyl glycerols and wax esters of acoustic (mandibular canal and melon) and blubber tissues. Biochimica et Biophysica Acta (BBA): Lipids and Lipid Metabolism, 231, 415-418: https://doi. org/10.1016/0005-2760(71)90158-5

Verrier, D., Groscolas, R., Guinet, C., \& Arnould, J. P. Y. (2011). Development of fasting abilities in subantarctic fur seal pups: Balancing the demands of growth under extreme nutritional restrictions. Functional Ecology, 25, 704-717. https://doi.org/10.1111/j.1365-2435.2010. 01823.x

Whitehead, H., Gowans, S., Faucher, A., \& McCarrey, S. W. (1997). Population analysis of northern bottlenose whales in the Gully, Nova Scotia. Marine Mammal Science, 13, 173-185. https://doi.org/10.1111/ j.1748-7692.1997.tb00625.x

Whitehead, H., \& Hooker, S. K. (2012). Uncertain status of the northern bottlenose whale Hyperoodon ampullatus: Population fragmentation, legacy of whaling and current threats. Endangered Species Research, 19, 47-61. https://doi.org/10.3354/esr00458

Williams, R., Vikingsson, G. A., Gislason, A., Lockyer, C., New, L., Thomas, L., \& Hammond, P. S. (2013). Evidence for density-dependent changes in body condition and pregnancy rate of North Atlantic fin whales over four decades of varying environmental conditions. ICES Journal of Marine Science: Journal du Conseil, 70, 1273-1280. https://doi.org/ 10.1093/icesjms/fst059

Young, R. A. (1976). Fat, energy and mammalian survival. American Zoologist, 16, 699-710. https://doi.org/10.1093/icb/16.4.699

Zuur, A. F., leno, E. N., \& Elphick, C. S. (2010). A protocol for data exploration to avoid common statistical problems. Methods in Ecology and Evolution, 1, 3-14. https://doi.org/10.1111/j.2041-210X.2009. 00001.x

How to cite this article: Kershaw JL, Brownlow A, Ramp CA, Miller PJO, Hall AJ. Assessing cetacean body condition: Is total lipid content in blubber biopsies a useful monitoring tool? Aquatic Conserv: Mar Freshw Ecosyst. 2019;29(S1):271-282. https://doi.org/10.1002/aqc.3105 